\title{
Use of constructed wetland systems with Arundo and Sarcocornia for polishing high salinity tannery wastewater
}

\author{
Cristina S.C. Calheiros ${ }^{\mathrm{a}}$, Paula V.B. Quitério ${ }^{\mathrm{a}}$, Gabriela Silva ${ }^{\mathrm{a}}$, Luís F.C. Crispim ${ }^{\mathrm{b}}$, Hans Brix ${ }^{\mathrm{c}}$, \\ Sandra C. Moura ${ }^{a}$, Paula M.L. Castro ${ }^{\mathrm{a}, *}$ \\ ${ }^{a}$ CBQF/Escola Superior de Biotecnologia, Universidade Católica Portuguesa, Rua Dr. António Bernardino de Almeida, 4200-072 Porto, Portugal \\ ${ }^{\mathrm{b}}$ Centro Tecnológico das Industrias do Couro, Apartado 158, São Pedro, 2384-909 Alcanena, Portugal \\ ${ }^{\mathrm{c}}$ Department of Biological Sciences, Aarhus University, Ole Worms Allé 1, 8000 Århus C., Denmark
}

\section{A R T I C L E I N F O}

\section{Article history}

Received 22 March 2011

Received in revised form

4 August 2011

Accepted 9 October 2011

Available online 4 November 2011

\section{Keywords:}

Biochemical oxygen demand

Leather industry

Nitrogen

Phosphorus

Treatment wetland

Constructed wetland

High salinity wastewater

\begin{abstract}
A B S T R A C T
Treatment of tannery wastewater is problematic due to high and variable concentrations of complex pollutants often combined with high salinity levels. Two series of horizontal subsurface flow constructed wetlands (CWs) planted with Arundo donax and Sarcocornia fruticosa were set up after a conventional biological treatment system operating at a tannery site. The aim of the CWs was polishing organics and nitrogen from the high salinity effluent $\left(2.2-6.6 \mathrm{~g} \mathrm{Cl}^{-} \mathrm{L}^{-1}\right)$. Both plant species established and grew well in the CW. Arundo, however, had more vigorous growth and a higher capacity to take up nutrients. The CWs were efficient in removing COD and $\mathrm{BOD}_{5}$ with removal efficiencies varying between 51 and $80 \%$ for COD (inlet: $68-425 \mathrm{mg} \mathrm{L}^{-1}$ ) and between 53 and $90 \%$ for $\mathrm{BOD}_{5}$ (inlet: $16-220 \mathrm{mg} \mathrm{L}^{-1}$ ). Mass removal rates were up to $615 \mathrm{~kg} \mathrm{COD} \mathrm{ha}^{-1} \mathrm{~d}^{-1}$ and $363 \mathrm{BOD}_{5} \mathrm{~kg} \mathrm{ha}^{-1} \mathrm{~d}^{-1}$. Removal efficiencies were $40-93 \%$ for total $\mathrm{P}, 31-89 \%$ for $\mathrm{NH}_{4}^{+}$and $41-90 \%$ for Total Kjeldahl Nitrogen. CW systems planted with salt tolerant plant species are a promising solution for polishing saline secondary effluent from the tannery industry to levels fulfilling the discharge standards.
\end{abstract}

(c) 2011 Elsevier Ltd. All rights reserved.

\section{Introduction}

Leather, agro-food and petroleum industries are among the sectors that generate highly saline wastewaters due to their productive cycle. In the leather sector certain streams of effluents may contain as much as $80 \mathrm{~g} \mathrm{~L}^{-1}$ of $\mathrm{NaCl}$ (Lefebvre and Moletta, 2006). The presence of salts in high amounts in wastewaters may adversely affect the biological processes in the wastewater treatment systems since hypersaline effluents are often recalcitrant (Lefebvre and Moletta, 2006; Rhoades et al., 1992). Constructed wetlands (CWs) are robust biological systems that can be applied for the treatment of several types of polluted water (Brix, 1994; Vymazal et al., 2006). CWs have been successfully applied for treatment of domestic sewage (Brix et al., 2011; El Hamouri et al., 2007; Konnerup et al., 2009; Trang et al., 2010), tannery wastewater (Calheiros et al., 2009; Emmanuel and Anand, 2007), piggery manure (Dan et al., 2011; Kantawanichkul et al., 2009; Meers et al., 2008) and fishpond water (Konnerup et al., 2011). However, the

\footnotetext{
* Corresponding author. Tel.: +351 22 5580059; fax: +351 225090351.

E-mail address: plcastro@esb.ucp.pt (P. M.L. Castro).
}

biological treatment processes may be inhibited by high salt concentrations (Lefebvre and Moletta, 2006). This has been scarcely studied in CWs (Karajić et al., 2010).

The wetland plants growing in CWs are important since they possess several functions in relation to the water treatment (Brix, 1997). The most commonly used plants are robust and fastgrowing species of emergent wetland plants (Vymazal and Kröpfelová, 2008), such as Typha latifolia and Phragmites australis (Brisson and Chazarenc, 2009). However, when dealing with high salinity wastewater caution must given to plant selection as they should be salt tolerant in order to have a resilient and effective CW system. Klomjek and Nitisoravut (2005) evaluated the feasibility of using CWs to remove pollutants from saline wastewaters using eight plant species. They reported that cattail (Typha angustifolia) had the best plant growth and nitrogen assimilation whereas Asia crabgrass (Digitaria bicornis) was superior for $\mathrm{BOD}_{5}$ removal when compared to the other species (Cyperus corymbosus, Brachiaria mutica, Vetiveria zizaniodes, Spartina patents, Leptochloa fusca and Echinodorus cordifolius). Kaseva and Mbuligwe (2010) found that a CW planted with Phragmites mauritanus was effective in removing chromium from a wastewater with a high content of dissolved solids (approx. $11 \mathrm{~g} \mathrm{~L}^{-1}$ ). Hence, CWs may have potential 
to treat saline wastewaters, but the selection of plant species may be important.

The aim of the present study was to assess the potential of using a horizontal subsurface flow CW system for polishing organics and nitrogen from a tannery wastewater with a high salinity. Two plant species were tested: Arundo donax (L), which is a large and robust grass commonly found in the surroundings of the study site, and Sarcocornia fruticosa (L.) A.J. Scott, which dominate local salt marshes and hence is tolerant towards exposure to saline water. The treatment performance of the experimental CW systems were monitored for COD, BOD, TSS, TDS, $\mathrm{N}\left(\mathrm{TKN}, \mathrm{NO}_{3}^{-}, \mathrm{NH}_{4}^{+}\right)$and TP removal. Furthermore, the propagation and growth of the two plant species and their uptake of $\mathrm{N}$ and $\mathrm{P}$ were assessed.

\section{Material and methods}

\subsection{Constructed wetlands set-up}

Two horizontal subsurface flow CWs (each with an area of $72 \mathrm{~m}^{2}$ and a bed depth of $0.35 \mathrm{~m}$ ) were set-up at a leather company in the centre of Portugal ( $\mathrm{N} 39^{\circ} 21^{\prime} 37.44^{\prime \prime}, \mathrm{W} 8^{\circ} 45^{\prime} 41.04^{\prime \prime}$ ) for polishing the tannery wastewater after a conventional secondary treatment system (activated sludge). This region is considered to have a warm temperate climate with dry summer (Kottek et al., 2006). During the sampling period, the air temperature at the site varied between 11 and $27^{\circ} \mathrm{C}$. Each CW system was subdivided into three beds and planted with either A. donax (designated as CWA - Arundo-planted CW) or S. fruticosa (designated as CWS - Sarcocornia-planted CW) (Fig. 1). The substrate in the beds consisted of equal parts of Filtralite $^{\circledR}$ NR 3-8 (particle size 3-8 mm), and washed sand (particle size $4-8 \mathrm{~mm}$ ). This media has been studied previously showing low adsorption capacity for organic matter (Calheiros et al, 2008). The A. donax used in the CW was transplanted from the surroundings of the wastewater discharge site of the leather company, and the $S$. fruticosa was transplanted from a nearby salt marsh. The plants were planted by hand at a density of 3 plants per $\mathrm{m}^{2}$. Feeding of wastewater to the system was made through a perforated polyvinylchloride (PVC) rigid pipe with a hydraulic flow control. During the initial two months after planting, the systems were first fed with a stream $\left(4 \mathrm{~m}^{3} \mathrm{~d}^{-1}\right)$ of unpolluted water (one month) and subsequently, for another month, that continuous stream was mixed with the wastewater coming from the conventional secondary treatment system (50\% wastewater). During the following 180 days each system was loaded with $4 \mathrm{~m}^{3} \mathrm{~d}^{-1}$ of

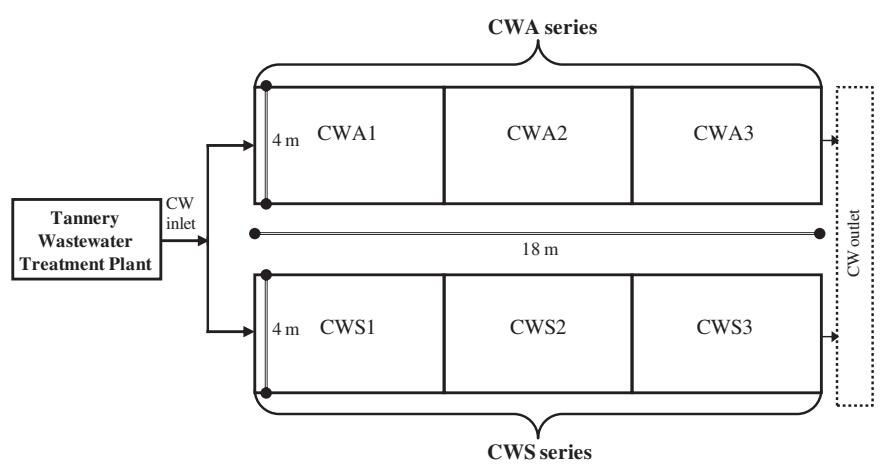

Fig. 1. Schematic representation of the experimental constructed wetland (CW) system consisting of two lines planted with Arundo donax and Sarcocornia fruticosa, respectively. CWA: CW planted with Arundo donax sectioned in bed CWA1, CWA2 and CWA3. CWS: CW planted with Sarcocornia fruticosa. sectioned in bed CWS1, CWS2 and CWS3. treated wastewater from the leather industry (corresponding to a hydraulic loading rate (HLR) of $60 \mathrm{~mm} \mathrm{~d}^{-1}$ and a hydraulic retention time (HRT) of 2 days). After this period the first beds had to be taken out of operation due to an accidental sludge spill in the first unit of each series. The first beds were then bypassed for the following 125 days and the flow increased to $10 \mathrm{~m}^{3} \mathrm{~d}^{-1}$ (corresponding to an HLR of $210 \mathrm{~mm} \mathrm{~d}^{-1}$ and a HRT of 0.6 days). The systems were inspected at least on a weekly basis to control the overall functioning.

\subsection{Physico-chemical analysis}

The system was monitored for 370 days, operating at a HLR of $60 \mathrm{~mm} \mathrm{~d}^{-1}$ between day 60 to 240 and at a HLR of $210 \mathrm{~mm} \mathrm{~d}^{-1}$ between day 241 and 370 . Grab samples were taken approximately three times per month at the inlet and outlet of each CW bed and the following parameters were analysed based on Standard Methods (APHA, 1998): chemical oxygen demand (COD), biochemical oxygen demand $\left(\mathrm{BOD}_{5}\right)$, total suspended solids (TSS), total dissolved solids (TDS), Total Kjeldahl Nitrogen (TKN), nitrate nitrogen $\left(\mathrm{NO}_{3}^{-}\right)$, ammonium nitrogen $\left(\mathrm{NH}_{4}^{+}\right)$, total phosphorus (TP), and chloride $\left(\mathrm{Cl}^{-}\right)$. The dissolved oxygen (DO), temperature, $\mathrm{pH}$ and conductivity were monitored on-site with a WTW handheld multiparameter instrument 340i at the inlet and outlet of the beds.

\subsection{Plant growth and tissue analysis}

Plants were visually inspected on a weekly basis for signs of toxicity such as chlorosis, necrosis and malformation. The shoot density and shoot height (starting from the substrate level) of eighteen plants from each CW bed were monitored at least monthly during the initial 240 days after planting (corresponding to the period with an HLR of $60 \mathrm{~mm} \mathrm{~d}^{-1}$ ). For chlorophyll analysis, three plants were randomly selected from each bed (CWA2, CWA3, CWS2 and CWS3) by the end of the period with an HLR of $210 \mathrm{~mm} \mathrm{~d}^{-1}$. Three circular discs of leaves from each plant were cut with a $10.5 \mathrm{~mm}$ corer, and were extracted in $\mathrm{N}, \mathrm{N}^{\prime}$ - dimethylformamide for Chlorophyll $a$ and $b$ analysis according to Wellburn (1994). In addition, four randomly selected specimens of each plant species were collected for dry biomass determination $\left(70{ }^{\circ} \mathrm{C}\right.$ for $48 \mathrm{~h}$ in an oven) and analysis of tissue concentrations of phosphorus (P) and nitrogen $(\mathrm{N})$. Concentrations of $\mathrm{N}$ and $\mathrm{P}$ in leaves, stems and roots were analysed by colorimetry (Helios Gamma, Unicam, Cambridge, UK) following the procedure of Wallinga et al. (1989).

\subsection{Data analysis}

Statistical analyses were performed using the software SPSS (SPSS Inc., Chicago, IL, USA; Version 12.0). The data were analyzed by Student's $t$-test. Values are generally presented as the mean \pm 1 standard error. Spearman's correlation analyses were performed to study possible correlations between the different variables (COD and $\mathrm{BOD}_{5}$ removal efficiencies and the organic mass removal rates for each Arundo and Sarcocornia-planted bed versus the wastewater temperature and the air temperature).

\section{Results and discussion}

Wastewater from the tanning industry is characterized by high organic loadings due to the processes used to turn raw hide or skin into leather, a non-putrescible product. Subsurface flow CWs have been used with success for the secondary treatment of wastewaters with high contents of organics (Calheiros et al., 2008, 2009; Dan et al., 2011; Kantawanichkul et al., 2009). However, in addition to the high organics contents, tannery wastewater may also contain 
Table 1

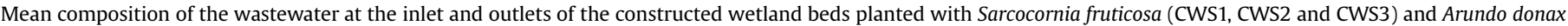
(CWA1, CWA2 and CWA3) at an HLR of $60 \mathrm{~mm} \mathrm{~d}^{-1}$. The three beds were operated in series. Minimum and maximum values are indicated in brackets.

\begin{tabular}{|c|c|c|c|c|c|c|c|c|}
\hline \multirow[t]{2}{*}{ Parameters } & \multirow{2}{*}{$\begin{array}{l}\text { Number of } \\
\text { samples }\end{array}$} & \multirow[t]{2}{*}{ Inlet } & \multicolumn{3}{|c|}{ Sarcocornia-planted CWs } & \multicolumn{3}{|c|}{ Arundo-planted CWs } \\
\hline & & & CWS1 & CWS2 & CWS3 & CWA1 & CWA2 & CWA3 \\
\hline $\mathrm{pH}$ & 13 & $7.83(7.2-8.20)$ & $7.81(7.45-8.05)$ & $7.78(7.45-8.10)$ & $7.84(7.6-8.15)$ & $7.70(7.3-8.00)$ & $7.57(7.35-7.90)$ & $7.54(7.35-7.90)$ \\
\hline $\mathrm{COD}\left(\mathrm{mg} \mathrm{L}^{-1}\right)$ & 19 & $194(68-285)$ & $124(50-202)$ & $92(39-155)$ & $67(28-120)$ & $127(53-194)$ & $95(37-160)$ & $69(27-120)$ \\
\hline $\mathrm{BOD}_{5}\left(\mathrm{mg} \mathrm{L}^{-1}\right)$ & 19 & $45(16-88)$ & $25(10-40)$ & $17(6-23)$ & $12(4-17)$ & $24(10-37)$ & $15(6-24)$ & $11(4-16)$ \\
\hline $\mathrm{DO}\left(\mathrm{mg} \mathrm{L}^{-1}\right)$ & 13 & $1.4(0.5-2.8)$ & $0.8(0.3-2.0)$ & $0.8(0.3-1.8)$ & $1.3(0.5-2.0)$ & $0.9(0.2-2.1)$ & $0.7(0.2-1.7)$ & $1.2(0.8-1.9)$ \\
\hline $\mathrm{TSS}\left(\mathrm{mg} \mathrm{L}^{-1}\right)$ & 11 & $91(40-146)$ & $64(30-114)$ & $46(20-81)$ & $33(15-57)$ & $59(29-91)$ & $44(21-73)$ & $30(14-58)$ \\
\hline $\operatorname{TDS}\left(\mathrm{g} \mathrm{L}^{-1}\right)$ & 11 & $10.4(4.2-12.3)$ & $10.0(4.1-12.0)$ & $9.5(4.0-11.7)$ & $8.9(3.3-10.7)$ & $10.0(4.1-12.1)$ & $9.4(4.0-11.6)$ & $8.8(3.3-10.5)$ \\
\hline Cond $\left(\mathrm{mS} \mathrm{cm}^{-1}\right)$ & 13 & $16.7(13.3-19.3)$ & $16.1(9.9-18.0)$ & $15.9(11.8-17.9)$ & 16.1(13.1-17.9) & $16.5(12.8-18.1)$ & $16.9(15.2-19.7)$ & $16.6(13.4-19.5)$ \\
\hline $\mathrm{Cl}^{-}\left(\mathrm{g} \mathrm{L}^{-1}\right)$ & 11 & $5.4(2.2-6.6)$ & $5.2(2.2-6.5)$ & $5.0(2.2-6.4)$ & $4.7(2.1-6.1)$ & $5.2(2.3-6.8)$ & $5.0(2.2-6.6)$ & $4.7(2.1-6.2)$ \\
\hline $\mathrm{TP}\left(\mathrm{mg} \mathrm{L}^{-1}\right)$ & 11 & $1.46(0.55-3.00)$ & $0.64(0.26-0.90)$ & $0.48(0.2-0.70)$ & $0.31(0.1-0.54)$ & $0.60(0.3-1.00)$ & $0.43(0.2-0.66)$ & $0.25(0.09-0.41)$ \\
\hline TKN $\left(\mathrm{mg} \mathrm{L}^{-1}\right)$ & 8 & $16.3(3.9-34.2)$ & $8.4(2.0-17.6)$ & $6.9(1.8-12.7)$ & $4.1(1.4-7.5)$ & $8.2(2.0-20.5)$ & $5.9(1.7-11.1)$ & $3.9(1.4-7.8)$ \\
\hline $\mathrm{NH}_{4}^{+}\left(\mathrm{mg} \mathrm{L}^{-1}\right)$ & 8 & $6.7(0.1-20.0)$ & $4.6(<0.1-11.0)$ & $2.7(<0.1-8.0)$ & $1.8(<0.1-5.4)$ & $4.6(<0.1-11.7)$ & $2.9(<0.1-7.6)$ & $1.8(<0.1-5.8)$ \\
\hline $\mathrm{NO}_{3}^{-}\left(\mathrm{mg} \mathrm{L}^{-1}\right)$ & 8 & $2.0(0.7-3.8)$ & $0.9(<0.1-2.3)$ & $0.4(<0.1-1.0)$ & $0.1(<0.1-0.2)$ & $0.9(<0.1-1.9)$ & $0.3(<0.1-0.8)$ & $0.1(<0.1-0.1)$ \\
\hline
\end{tabular}

high concentrations of salts that may affect the microbial degradation processes in the wastewater treatment systems. In this study the performance, in terms of contaminant removal with special focus on $\mathrm{BOD}_{5}$ and $\mathrm{COD}$, and plant development of two series of CW beds planted with $A$. donax and $S$. fruticosa polishing tannery wastewater, was evaluated for more than one year at two different HLRs of 60 and $210 \mathrm{~mm} \mathrm{~d}^{-1}$. The wastewater used in this study originated from a conventional secondary treatment system. Thus COD and $\mathrm{BOD}_{5}$ levels were generally low: $68-425 \mathrm{mg} \mathrm{L}^{-1}$ for COD and $16-220 \mathrm{mg} \mathrm{L}^{-1}$ for $\mathrm{BOD}_{5}$. The wastewater was considered to be highly saline with electric conductivities of $13.3-19.3 \mathrm{mS} \mathrm{cm}^{-1}$ and TDS concentrations of $4220-12300 \mathrm{mg} \mathrm{L}^{-1}$. For plant selection, it was given as prerogative that plants should be present in the surroundings of the site and/or to have evidence of being resilient to high salinity wastewater. A. donax was abundant at the site of the wastewater discharge, and this species has previously been used with success in CW systems treating sewage (El Hamouri et al., 2007; Mavrogianopoulos et al., 2002). S. fruticosa is a species typical of salt marshes and are inherently adapted to grow at high salinities (Alonso and Crespo, 2008; Redondo et al., 2004).

\subsection{Constructed wetland performance}

The performance of the CW systems at the two HLRs of 60 and $210 \mathrm{~mm} \mathrm{~d}^{-1}$ are presented in Tables 1 and 2, respectively. Fig. 2 presents COD removal in the individual beds operated in series (first CW1, second CW2 and third CW3). Removal efficiencies for COD and $\mathrm{BOD}_{5}$ were high, up to $80 \%$ for an inlet COD of $68-425 \mathrm{mg} \mathrm{L}^{-1}$ and up to $90 \%$ for an inlet $\mathrm{BOD}_{5}$ of $16-220 \mathrm{mg} \mathrm{L}^{-1}$. No significant differences were seen in $\mathrm{COD}$ and $\mathrm{BOD}_{5}$ removal between the two series for each HLR applied, although Calheiros et al. (2009) found that removal efficiency decreased with HLR. These findings may be attributed to the fact that in the present study the organic loadings were relatively low as the CW systems were receiving secondarily treated wastewater. Linear correlations between mass loading rates and mass removal rates of COD (CWA: $\mathrm{R}^{2}=0.9846$; CWS: $\mathrm{R}^{2}=0.984$ ) and $\mathrm{BOD}_{5}$ were found (Fig. 3; data for $\mathrm{BOD}_{5}$ not shown), illustrating the capacity of the system to remove COD and BOD, as previously shown (Calheiros et al, 2009). The maximum organic loading rates were $615 \mathrm{~kg} \mathrm{COD} \mathrm{ha}^{-1} \mathrm{~d}^{-1}$ and $363 \mathrm{~kg} \mathrm{BOD} \mathrm{ha}^{-1} \mathrm{~d}^{-1}$ which is significant lower than the loads in the study by Calheiros et al. (2009), who found maximum organic mass removals of $1294 \mathrm{~kg} \mathrm{COD} \mathrm{ha}^{-1} \mathrm{~d}^{-1}$ and $520 \mathrm{~kg} \mathrm{BOD}_{5} \mathrm{ha}^{-1} \mathrm{~d}^{-1}$. Spearman's correlation analyses of the COD and $\mathrm{BOD}_{5}$ removal efficiencies and the organic mass removal rates (in terms of $\mathrm{kg}$ COD and $\mathrm{BOD}_{5} \mathrm{ha}^{-1} \mathrm{~d}^{-1}$ ) for each Arundo and Sarcocornia-planted bed versus the wastewater temperature and the air temperature (at the time of sampling) showed no statistically significant $(\mathrm{p}<0.05)$ relationships between any of these factors.

TSS removal did not differ significantly between the Arundo and the Sarcocornia-planted beds and did also not differ between loading rates. The concentrations of dissolved solids in the water were high (TDS 4220 to $12300 \mathrm{mg} \mathrm{L}^{-1}$ ) and TDS were barely removed in the CWs (removal efficiencies 2-30\%). Chlorine concentrations were also high (2200-6600 $\left.\mathrm{mg} \mathrm{L}^{-1}\right)$ in the inlet and decreased up to $32 \%$ at the outlet. Emmanuel and Anand (2007) presented a reduction of $16 \%$ and $50 \%$ for COD (inlet: $465 \mathrm{mg} \mathrm{L}^{-1}$ ) and BOD (inlet: $28 \mathrm{mg} \mathrm{L}^{-1}$ ), respectively, in a reed bed used to improve tannery wastewater after a conventional secondary treatment. This wastewater had a high content of TDS

Table 2

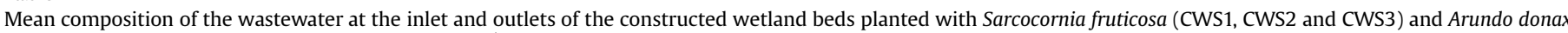

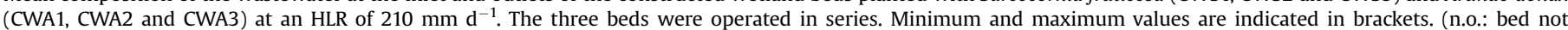
operational).

\begin{tabular}{|c|c|c|c|c|c|c|c|c|}
\hline \multirow[t]{2}{*}{ Parameters } & \multirow{2}{*}{$\begin{array}{l}\text { Number of } \\
\text { samples }\end{array}$} & \multirow[t]{2}{*}{ Inlet } & \multicolumn{3}{|c|}{ Sarcocornia-planted CWs } & \multicolumn{3}{|c|}{ Arundo-planted CWs } \\
\hline & & & CWS1 & CWS2 & CWS3 & CWA1 & CWA2 & CWA3 \\
\hline $\mathrm{pH}$ & 9 & $7.84(7.6-8.00)$ & n.o. & $7.81(7.60-8.10)$ & $7.79(7.55-8.00)$ & n.o. & $7.69(7.50-8.15)$ & $7.67(7.50-7.95)$ \\
\hline $\operatorname{COD}\left(\mathrm{mg} \mathrm{L}^{-1}\right)$ & 11 & $249(190-425)$ & n.o. & $130(80-197)$ & $100(77-167)$ & n.o. & $123(78-187)$ & $92(68-130)$ \\
\hline $\mathrm{BOD}_{5}\left(\mathrm{mg} \mathrm{L}^{-1}\right)$ & 11 & $67(20-220)$ & n.o. & $25(5-69)$ & $16(4-52)$ & n.o. & $21(6-62)$ & $14(4-46)$ \\
\hline $\mathrm{DO}\left(\mathrm{mg} \mathrm{L}^{-1}\right)$ & 9 & $1.2(0.2-3.1)$ & n.o. & $1.0(0.5-2.5)$ & $1.0(0.4-2.1)$ & n.o. & $0.9(0.1-2.6)$ & $1.0(0.4-2.1)$ \\
\hline $\mathrm{TSS}\left(\mathrm{mg} \mathrm{L}^{-1}\right)$ & 9 & $73(45-104)$ & n.o. & $37(22-52)$ & $27(10-39)$ & n.o. & $37(26-52)$ & $24(10-38)$ \\
\hline $\operatorname{TDS}\left(\mathrm{g} \mathrm{L}^{-1}\right)$ & 9 & $11.1(10.7-11.4)$ & n.o. & $10.4(9.8-11.2)$ & $10.0(9.5-10.6)$ & n.o. & $10.4(9.7-11.0)$ & $10.1(9.1-10.8)$ \\
\hline Cond $\left(\mathrm{mS} \mathrm{cm}^{-1}\right)$ & 9 & $17.4(16.4-18.4)$ & n.o. & $16.8(15.3-18.3)$ & $16.5(14.8-18.1)$ & n.o. & $17.2(15.9-18.2)$ & $16.8(15.9-18.2)$ \\
\hline $\mathrm{Cl}^{-}\left(\mathrm{g} \mathrm{L}^{-1}\right)$ & 9 & $5.9(5.2-6.3)$ & n.o. & $5.6(4.9-6.2)$ & $5.5(4.9-6.1)$ & n.o. & $5.6(4.9-6.1)$ & $5.5(4.8-6.0)$ \\
\hline $\mathrm{TP}\left(\mathrm{mg} \mathrm{L}^{-1}\right)$ & 9 & $0.71(0.40-1.53)$ & n.o. & $0.35(0.10-0.60)$ & $0.22(0.1-0.30)$ & n.o. & $0.29(0.08-0.43)$ & $0.18(0.10-0.27)$ \\
\hline $\mathrm{TKN}\left(\mathrm{mg} \mathrm{L}^{-1}\right)$ & 5 & $10.4(8.9-12.4)$ & n.o. & $6.5(4.9-8.5)$ & $4.9(3.8-5.7)$ & n.o. & $5.9(3.1-8.5)$ & $4.3(2.6-5.2)$ \\
\hline $\mathrm{NH}_{4}^{+}\left(\mathrm{mg} \mathrm{L}^{-1}\right)$ & 5 & $3.9(2.2-6.6)$ & n.o. & $2.6(1.1-4.5)$ & $1.5(0.9-3.5)$ & n.o. & $2.3(1.1-3.9)$ & $1.5(0.9-3.4)$ \\
\hline $\mathrm{NO}_{3}^{-}\left(\mathrm{mg} \mathrm{L}^{-1}\right)$ & 5 & $23.1(9.1-56.6)$ & n.o. & $6.6(1.0-15.0)$ & $1.0(<0.1-2.0)$ & n.o. & $6.0(0.8-16.0)$ & $1.0(<0.1-2.0)$ \\
\hline
\end{tabular}



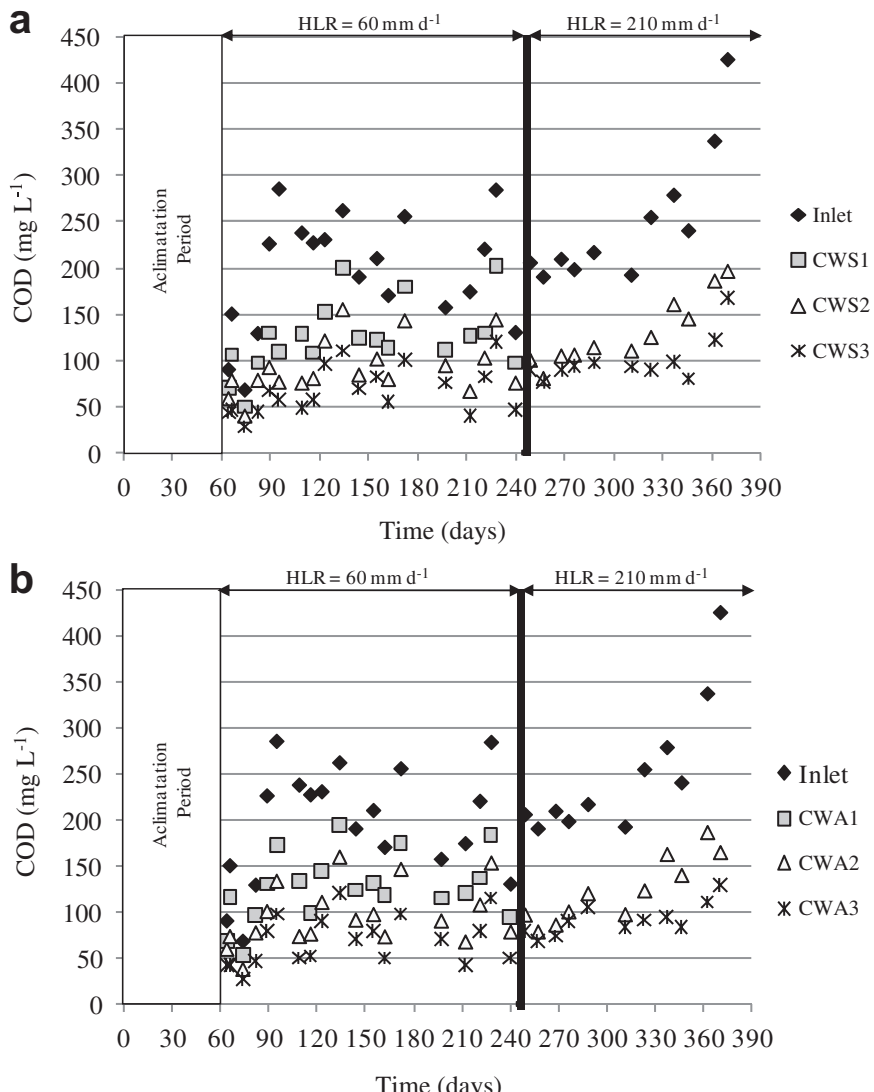

Fig. 2. COD at the inlet and outlet of each constructed wetland (CW) series beds during the time of operation. a) CWS: CW with Sarcocornia fruticosa. (beds: CWS1, CWS2 and CWS3) and b) CWA: CW series planted with Arundo donax (beds: CWA1, CWA2 and CWA3).

(5550 mg L $\mathrm{L}^{-1}$ ) which was reduced by only $1.3 \%$, though in the present study a decrease up to $30 \%$ was registered for an inlet TDS varying between 4220 and $12298 \mathrm{mg} \mathrm{L}^{-1}$. Daniels (2007) found that reed beds performed well treating tannery clarified effluent with a TDS concentration of $11500 \mathrm{mg} \mathrm{L}^{-1}$ and achieved removal efficiencies of $90 \%$ for COD (inlet: $2500 \mathrm{mg} \mathrm{L}^{-1}$ ) and $92 \%$ for BOD (inlet $800 \mathrm{mg} \mathrm{L}^{-1}$ ). Also Karajić et al. (2010), who used a pilot scale horizontal flow CW to treat saline wastewater, concluded that salinity did not have a strong influence on the removal efficiency of COD. This supports the findings of the present study.

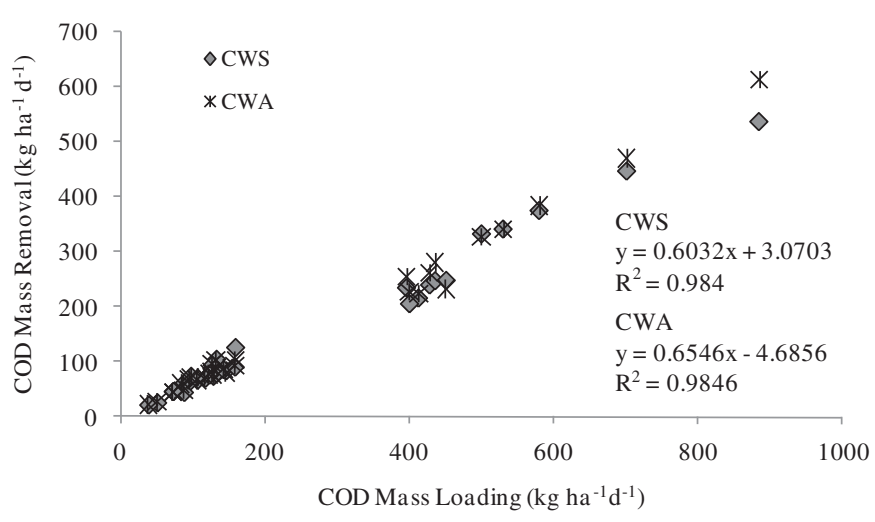

Fig. 3. COD mass removal vs. COD mass loading for the constructed wetland: planted with Arundo donax (CWA) and planted with Sarcocornia fruticosa (CWS).
Phosphorus and nitrogen are generally removed less efficiently in horizontal subsurface flow CWs than COD and $\mathrm{BOD}_{5}$ (Vymazal et al., 2006; Vymazal and Kröpfelová, 2008). As an example, El Hamouri et al. (2007) reported a TKN removal of only $11 \%$ at an inlet concentration of $60 \mathrm{mg} \mathrm{L}^{-1}$, and only $8 \%$ removal of $\mathrm{NH}_{4}^{+}-\mathrm{N}$ at an inlet concentration of $63 \mathrm{mg} \mathrm{L}^{-1}$ in a CW planted with $A$. donax. In the present study we found significantly higher removal of nutrients, namely $40-93 \%$ for total $\mathrm{P}, 31-89 \%$ for $\mathrm{NH}_{4}^{+}$and $41-90 \%$ for TKN. However, the systems did not nitrify the effluent. Overall the effluent from the CW system fulfilled the Portuguese discharge limits for tanneries concerning COD, $\mathrm{BOD}_{5}, \mathrm{TSS}, \mathrm{NH}_{4}^{+}, \mathrm{NO}_{3}^{-}$and $\mathrm{pH}$ (Portaria n.o 512/92 de 22 de Junho and Decreto-Lei n.o 236/98 de 1 de Agosto).

\subsection{Plant growth and development}

Both wetland species established and developed well in the CWs, without showing signs of toxicity. Occasionally, and coinciding with high air temperatures, the $A$. donax leaves were infested by aphids, but the infestation did not seem to affect the plant growth. The shoot density increased from 3 per $\mathrm{m}^{2}$ at the start of the experiment to more than 17 per $\mathrm{m}^{2}$ for $A$. donax beds and more than 5 per $\mathrm{m}^{2}$ for $S$. fruticosa beds by the end of the monitoring period at day 240 (Fig. 4). By the end of the trial the average plant height of $S$. fruticosa was $25 \pm 1 \mathrm{~cm}$ that of $A$. donax $97 \pm 3 \mathrm{~cm}$. The density and development of $A$. donax during the trial was better than that of $S$. fruticosa due to the different intrinsic characteristics of the two species. The A. donax root system was deeper and more
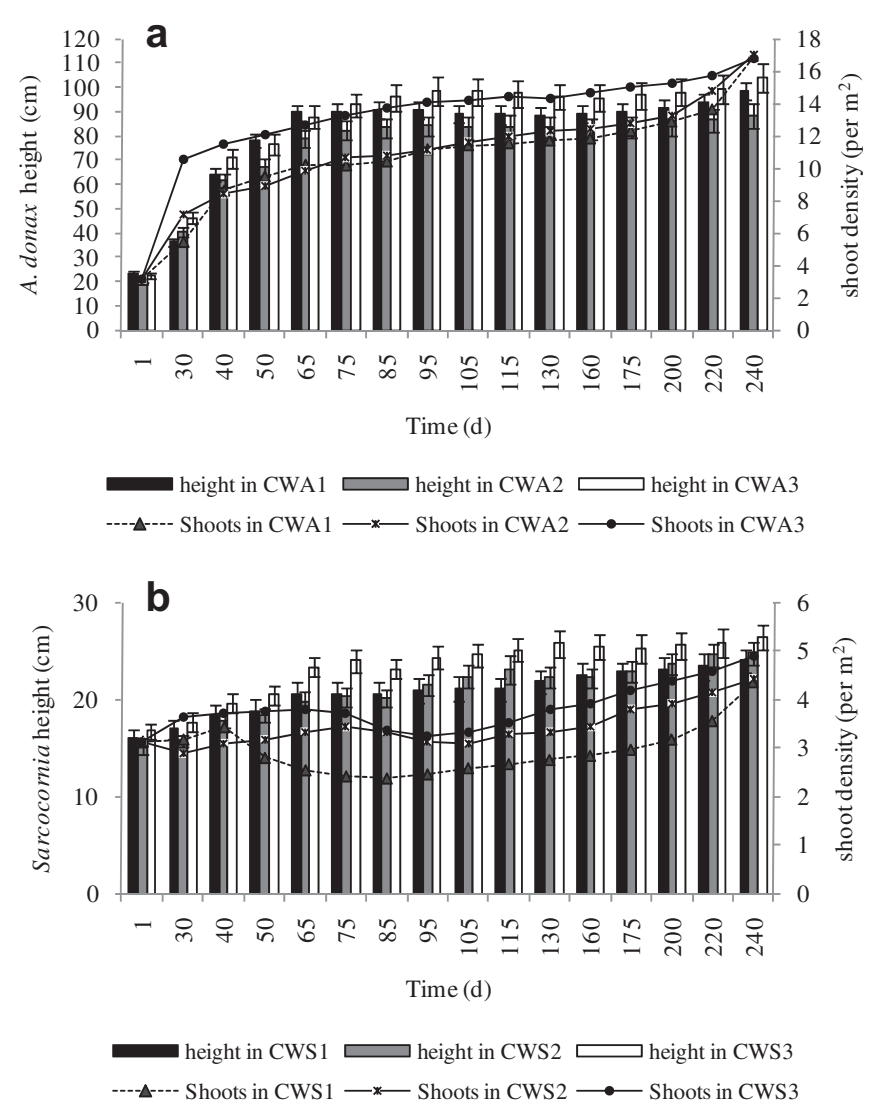

Fig. 4. Variation in shoot density and plants height in the constructed wetland (CW) series at different sampling times. CWA: CW planted with Arundo donax and CWS: CW with Sarcocornia fruticosa. Results are shown for: a) CWA beds (CWA1, CWA2 and CWA3) and b) CWS beds (CWS1, CWS2 and CWS3). The values of plant height per column are means of eighteen observations \pm SE. 
Table 3

Mean ( \pm standard error) concentrations of Chlorophyll $a$ and $b$ in the leaves from the constructed wetland (CW) series. CWA: CW planted with Arundo donax (beds: CWA2 and CWA3) and CWS: CW planted with Sarcocornia fruticosa (beds: CWS2 and CWS3).

\begin{tabular}{|c|c|c|c|c|}
\hline \multirow{2}{*}{$\frac{\text { Vegetation }}{\text { CW bed }}$} & \multicolumn{2}{|c|}{ Sarcocornia-planted CW } & \multicolumn{2}{|c|}{ Arundo-planted CW } \\
\hline & CWS2 & CWS3 & CWA2 & CWA3 \\
\hline $\begin{array}{l}\text { Chlorophyll } a \\
\quad\left(\mathrm{mg} \mathrm{g}^{-1} \mathrm{FW}\right)\end{array}$ & $0.14 \pm 0.04$ & $0.20 \pm 0.05$ & $0.67 \pm 0.11$ & $0.69 \pm 0.04$ \\
\hline $\begin{array}{l}\text { Chlorophyll } b \\
\quad\left(\mathrm{mg} \mathrm{g}^{-1} \mathrm{FW}\right)\end{array}$ & $0.08 \pm 0.01$ & $0.09 \pm 0.02$ & $0.57 \pm 0.04$ & $0.65 \pm 0.03$ \\
\hline
\end{tabular}

developed than that of $S$. fruticosa. In nature A. donax may reach heights of up to 3-10 m, depending on growth conditions (Mavrogianopoulos et al., 2002). The concentrations of chlorophylls in the leaves are presented in Table 3.

The size of the A. donax plants harvested at the end of the study in the second bed (CWA2) varied between 108 and $365 \mathrm{~g}$ DW per plant (average: $232 \mathrm{~g} \mathrm{DW}$ ) and in the third bed (CWA3) between 59 and $407 \mathrm{~g}$ DW per plant (average: $204 \mathrm{~g} \mathrm{DW}$ ). For S. fruticosa the dry biomass varied between 7 and $84 \mathrm{~g}$ DW per plant (average: $48 \mathrm{~g}$ DW) in the second bed (CWS2), and 6 and $110 \mathrm{~g}$ DW per plant (average: $38 \mathrm{~g}$ ) in the third bed (CWS3). There was no substantial difference between the biomass of plants in bed 2 and bed 3 of any of the species, and the plant biomass did not correlate with tissue $\mathrm{N}$ and $\mathrm{P}$ concentrations. The $\mathrm{P}$ and $\mathrm{N}$ concentrations in the plant tissues did not differ significantly between the beds (Table 4). The concentrations of both $\mathrm{N}$ and $\mathrm{P}$ were however higher in A. donax than in S. fruticosa. This, coupled with the more vigorous growth and biomass development of $A$. donax compared to $S$. fruticosa indicates, that the role of the plants for the treatment processes, including nutrient uptake, is greater for $A$. donax than for S. fruticosa. A. donax is well adapted to the high disturbance dynamics of riparian systems (Bell, 1997) and has also shown high tolerance when irrigated with water containing the heavy metals cadmium and nickel (Papazoglou, 2007). Earlier studies have indicated that $A$. donax has a potential to treat saline wastewaters, $\mathrm{P}-$, and N-rich wastewaters and to produce high biomass yields (Williams et al., 2008). Also, Mavrogianopoulos et al. (2002) reported that the use of $A$. donax in a closed gravel hydroponic system would work not only as a biomass production system, but also as a wastewater cleaner for minerals and metals.

The role of plant nutrient uptake is however generally considered of limited importance in relation to nutrient removal in this type of CW system (Brix, 1997), which was probably also the case in this study.

\section{Table 4}

Mean ( \pm standard error) concentrations of nitrogen and phosphorus in the plant tissues collected at the constructed wetland (CW) series. CWA: CW planted with Arundo donax (beds: CWA2 and CWA3) and CWS: CW planted with Sarcocornia fruticosa (beds: CWS2 and CWS3).

\begin{tabular}{llrl}
\hline $\begin{array}{l}\text { Constructed } \\
\text { wetland }\end{array}$ & $\begin{array}{l}\text { Plant } \\
\text { tissue }\end{array}$ & $\begin{array}{l}\text { Nitrogen } \\
\left(\mathrm{mg} \mathrm{N} \mathrm{g} \mathrm{DW}^{-1}\right)\end{array}$ & $\begin{array}{l}\text { Phosphorus } \\
\left(\mathrm{mg} \mathrm{P} \mathrm{g} \mathrm{DW}^{-1}\right)\end{array}$ \\
\hline CWA2 & Leaf & $18.94 \pm 1.81$ & $0.90 \pm 0.06$ \\
& Stem & $6.87 \pm 1.43$ & $0.78 \pm 0.07$ \\
& Root & $5.40 \pm 0.59$ & $2.49 \pm 0.12$ \\
CWA3 & Leaf & $17.97 \pm 3.98$ & $0.75 \pm 0.06$ \\
& Stem & $8.80 \pm 1.01$ & $0.61 \pm 0.09$ \\
CWS2 & Root & $8.45 \pm 1.51$ & $1.12 \pm 0.03$ \\
& Shoot & $10.96 \pm 1.70$ & $0.79 \pm 0.12$ \\
CWS3 & Root & $3.34 \pm 0.31$ & $1.73 \pm 0.20$ \\
& Shoot & $12.06 \pm 1.21$ & $0.84 \pm 0.16$ \\
& Root & $5.39 \pm 0.63$ & $1.59 \pm 0.25$ \\
\hline
\end{tabular}

\section{Conclusions}

The present study indicates that CW systems can be successfully established for polishing of highly saline effluents from the tannery industry. Horizontal subsurface flow CWs proved to be very effective in removing BOD and COD, nitrogen and phosphorus from saline secondary effluent, and able to produce an effluent quality that fulfils the discharge standards. CWs should be established with several beds in parallel and/or in series to allow for operational flexibility. The plant species Arundo and Sarcocornia established and grew well in the CWs, however Arundo is considered the most promising species because of its deeper root system, its more vigorous growth and higher capacity to take up nutrients. Plants play an important role in CWs contaminant removal, and their favourable development is an indication of successful wastewater treatment.

\section{Acknowledgements}

This work was supported by the AdI, PRIME - IDEIA Programme, through the Project n. ${ }^{\circ}$ 70/00324 - Planticurt. Cristina S.C. Calheiros thanks a research grant from Fundação para a Ciência e Tecnologia (FCT), Portugal (SFRH/BPD/63204/2009).

\section{References}

Alonso, M.Á, Crespo, M.B., 2008. Taxonomic and nomenclatural notes on South American taxa of Sarcocornia (Chenopodiaceae). Ann. Bot. Fennici. 45, 241-254.

APHA, 1998. Standard Methods for the Examination of Water and Wastewater twentieth ed. American Public Health Association/American Water Works Association/Water Environment Federation, Washington DC, USA.

Bell, G.P. 1997. Ecology and management of Arundo donax, and approaches to riparian habitat restoration in Southern California. In: Wade, J.H., Pysek, P., Green, D. (Eds.), Plant Invasions: Studies from North America and Europe. Blackhuys Publishers, Leiden, The Netherlands, pp. 103-113.

Brisson, J., Chazarenc, F., 2009. Maximizing pollutant removal in constructed wetlands: should we pay more attention to macrophyte species selection? Sci. Tot. Environ. 407, 3923-3930.

Brix, H., 1994. Use of constructed wetlands in water pollution control: historical development, present status, and future perspectives. Water Sci. Technol. 30 (8), 209-223.

Brix, H., 1997. Do macrophytes play a role in constructed treatment wetlands? Water Sci. Technol. 35 (5), 11-17.

Brix, H., Koottatep, T., Fryd, O., Laugesen, C.H., 2011. The flower and the butterfly constructed wetland system at Koh Phi Phi - System design and lessons learned during implementation and operation. Ecol. Eng. 37 (5), 729-735.

Calheiros, C.S.C., Rangel, A.O.S.S., Castro, P.M.L., 2008. Evaluation of different substrates to support the growth of Typha latifolia in constructed wetlands treating tannery wastewater over long-term operation. Bioresour. Technol. 99, 6866-6877.

Calheiros, C.S.C., Rangel, A.O.S.S., Castro, P.M.L., 2009. Treatment of industrial wastewater with two-stage constructed wetlands planted with Typha latifolia and Phragmites australis. Bioresour. Technol. 100 (13), 3205-3213.

Dan, T.H., Quang, L.N., Chiem, N.H., Brix, H., 2011. Treatment of high-strength wastewater in tropical constructed wetlands planted with Sesbania sesban: horizontal subsurface flow versus vertical downflow. Ecol. Eng. 37 (5), 711-720.

Daniels, R.P., 2007. Tannery effluent and reedbeds: working with nature. Jalca 102, $248-253$.

El Hamouri, B., Nazih, J., Lahjouj, J., 2007. Subsurface-horizontal flow constructed wetland for sewage treatment under Moroccan climate conditions. Desalination 215 (1-3), 153-158.

Emmanuel, K.V., Anand, G., 2007. Reedbeds: secondary and tertiary performance for tannery and other industrial effluents. World Leather: February/March, 41-43.

Karajić, M., Lapanje, A., Razinger, J., Zrimec, A., Vrhovšek, D., 2010. The effect of the application of halotolerant microorganisms on the efficiency of a pilot-scale constructed wetland for saline wastewater treatment. J. Serb. Chem. Soc. 75 (1), 129-142.

Kaseva, M.E., Mbuligwe, S.E., 2010. Potential of constructed wetland systems for treating tannery industrial wastewater. Water Sci. Technol. 61.4, 1043-1052.

Klomjek, P., Nitisoravut, S., 2005. Constructed treatment wetland: a study of eight plant species under saline conditions. Chemosphere 58, 585-593.

Kantawanichkul, S., Kladprasert, A., Brix, H., 2009. Treatment of high-strength wastewater in tropical vertical flow constructed wetlands planted with Typha angustifolia and Cyperus involucratus. Ecol. Eng. 35 (2), 238-247.

Konnerup, D., Koottatep, T., Brix, H., 2009. Treatment of domestic wastewater in tropical subsurface flow constructed wetlands planted with Canna and Heliconia. Ecol. Eng. 35 (2), 248-257. 
Konnerup, D., Trang, N.T.D., Brix, H., 2011. Treatment of fishpond water by recirculating horizontal and vertical flow constructed wetlands in the tropics. Aquaculture 313 (1-4), 57-64.

Kottek, M., Grieser, J., Beck, C., Rudolf, B., Rubel, F., 2006. World map of the Köppen-Geiger climate classification updated. Meteorol. Z. 15 (3), 259-263.

Lefebvre, O., Moletta, R., 2006. Treatment of organic pollution in industrial saline wastewater: a literature review. Water Res. 40, 3671-3682.

Mavrogianopoulos, G., Vogli, V., Kyritsis, S., 2002. Use of wastewater as a nutrient solution in a closed gravel hydroponic culture of giant reed (Arundo donax). Bioresour. Technol. 82 (2), 103-107.

Meers, E., Tack, F.M.G., Tolpe, I., Michels, E., 2008. Application of a full-scale constructed wetland for tertiary treatment of piggery manure: monitoring results. Water Air Soil Pollut. 193, 15-24.

Papazoglou, E.G., 2007. Arundo donax L. stress tolerance under irrigation with heavy metal aqueous solutions. Desalination 211, 304-313.

Redondo, S., Rubio-Casal, A.E., Castillo, J.M., Luque, C.J., Álvarez, A.A., Luque, T. Figueroa, M.E., 2004. Influences of salinity and light on germination of three Sarcocornia taxa with contrasted habitats. Aquat. Bot. 78 (3), 255-264.

Rhoades, J.D., Kandiah, A., Mashali, A.M., 1992. The Use of Saline Waters for Crop Production -FAO, Irrigation and Drainage Paper 48. Food and Agriculture Organization of the United Nations, Rome, Italy.
Trang, N.T.D., Konnerup, D., Schierup, H.-H., Chiem, N.H., Tuan, L.A., Brix, H., 2010. Kinetics of pollutant removal from domestic wastewater in a tropical horizontal subsurface flow constructed wetland system: effects of hydraulic loading rate. Ecol. Eng. 36 (4), 527-535.

Vymazal, J., Kröpfelová, L., 2008. Wastewater treatment in constructed wetlands with horizontal sub-surface flow. In: Alloway, B.J., Trevors, J.T. (Eds.), Environmental Pollution, vol. 14. Springer, The Netherlands.

Vymazal, J., Greenway, M., Tonderski, K., Brix, H., Mander, U., 2006. Constructed wetlands for wastewater treatment. In: Verhoeven, J.T.A., Beltman, B. Bobbink, R., Whigham, D.F. (Eds.), Wetlands and Natural Resource Management. Ecological Studies, vol. 190. Springer-Verlag, Berlin Heidelberg, pp. 69-96.

Wallinga, I., Vark, V.W., Houba, V.J.G., Lee, J.J., 1989. Plant Analysis Procedures (Soil and Plant Analysis. Part 7). A Series of Syllabi. Department of Soil Science and Plant Nutrition. Wageningen Agricultural University, Wageningen. The Netherlands.

Wellburn, A.R., 1994. The spectral determination of chlorophylls a and b, as well as total carotenoids, using various solvents with spectrophotometers of different resolution. J. Plant Physiol. 144, 307-313.

Williams, C.M.J., Biswas, T.K., Schrale, G., Virtue, J.G., Heading, S., 2008. Use of Saline Land and Wastewater for Growing a Potential Biofuel Crop (Arundo donax l) The Irrigation Australian Conference. Melbourne. Australia. 